\title{
A
}

Acta HealthMedica

Volume 3, Issue 1, February 2018, Pages: 239, DOI: http://dx.doi.org/10.19082/ah239

\section{BISPHENOL A EXPOSURE IS LINKED WITH UTERINE FIBROMA IN WESTERN ALGERIAN WOMEN OF CHILDBEARING AGE}

HananeYasmina Anteur, Malika Bendahmane, Hayet Mehida, Benali Beghdadli, Fadl-Allah Aboubekr, Naim Akhtar Khan, Baderdine Abbdel krim Kandouci

DjillaliLiabès University, Algeria

Email: yasmina-anteur@hotmail.fr

\section{TYPE OF ARTICLE: CONFERENCE ABSTRACT}

\begin{abstract}
Bisphenol A (BPA) is an endocrine disruptor chemical widely used in the manufacture of polycarbonate plastics and epoxy resins found in everyday consumer products including food and beverage containers. This molecule was recently incriminated as a potential initiator for a number of diseases such as uterine fibromas, a frequent gynecological benign tumor that affects women's fertility and life quality. The present study aims to investigate the association between uterine leiomyoma and BPA plasma levels in a population of Algerian women. Eighty plasma samples were collected from women with confirmed uterine fibroids diagnosis $(\mathrm{N}=40)$ and healthy volunteers without uterine leiomyomas $(\mathrm{N}=40)$ recruited at the specialized Hospital of Gynecology and Obstetrics of Sidi Bel Abbès in the western region of Algeria. Uterine leiomyoma subjects were then divided into three groups according to tumor growth and severity. BPA plasma levels were detected and measured using an enzyme linked immunosorbent assay (ELISA) technique. Seventy five percent of uterine leiomyoma patients were exposed to BPA and were principally young nulliparous women aged from 31 to 40 years expressing significantly higher plasma BPA levels than controls $(0.89 \pm 1.65$ vs $0.05 \pm 0.12 \mathrm{ng} / \mathrm{mL} ; \mathrm{P}=0.0001)$. Concerning the relationship between tumor growth and BPA levels, even though mean concentration was slightly higher in the severe group than the moderate group, the difference was statistically insignificant $(\mathrm{P}=0.97)$. These preliminary results suggest an association between environmental exposure to BPA and the occurrence of uterine fibroids among an Algerian female population of child-bearing age. Nevertheless, further studies on larger populations are required to confirm these findings.

KEYWORDS: Bisphenol A; Uterine fibromas; Algerian women; Childbearing age; ELISA
\end{abstract}

\footnotetext{
Abstracts of Second International Conference on Health Sciences and Medical Technologies, 10-12 October 2017, Tlemcen, Algeria (ICHSMT-17)

(C) 2018 The Authors. This is an open access article under the terms of the Creative Commons Attribution-NonCommercialNoDerivs License, which permits use and distribution in any medium, provided the original work is properly cited, the use is non-commercial and no modifications or adaptations are made.
} 